предупредить возникновение конфликта интересов в будущем, будет способствовать сокращению числа коррупционных возможностей и схем для их реализации.

$$
* * *
$$

1. Федеральный закон от 27.07.2004 N 79-Ф3 (ред. от 01.07.2017) «О государственной гражданской службе Российской Федерации» // Российская газета. - N 162. - 31.07.2004

2. Федеральный закон от 25.12.2008 N 273-Ф3 (ред. от 03.04.2017) «О противодействии коррупции» (с изм. и доп., вступ. в силу с 28.06.2017) // Российская газета. - N 266. - 30.12.2008

3. Указ Президента Российской Федерации от 01 февраля 2005 г № 112 «О конкурсе на замещение вакантной должности государственной гражданской службы Российской Федерации» // Российская газета. - N 20. - 03.02.2005

4. Методические рекомендации по проведению оценки коррупционных рисков в федеральных органах исполнительной власти, осуществляющих контрольно-надзорные функции (утв. протоколом заседания проектного комитета от 13.07.2017 N 47(7)) / http://www.rosmintrud.ru

5. Воронцов С.А. Рецензия на учебное пособие Соловьева А.В. «Конфликт корыстных интересов на государственной и муниципальной службе: природа и способы преодоления» // Наука и образование: хозяйство и экономика; предпринимательство; право и управление. 2014. №2 (45).

6. Петелин, Б. Я. Вина в структуре криминалистической характеристики преступлений / Б. Я. Петелин // Вопросы борьбы с преступностью. 2013. Вып. 43. - С. 54.

\title{
Овсянников Ю.Н. \\ О некоторых правовых аспектах реализации института правовой помощи по делам об административных правонарушениях
}

Северо-Западный институт управления - филиал Российской академии народного хозяйства и государственной службы при Президенте Российской Федерации (Россия, Санкт-Петербург)

doi:10.18411/lj-31-03-2018-66

idsp: 000001:lj-31-03-2018-66

\section{Аннотация}

В данной статье предпринята попытка анализа степени действенности норм Кодекса об административных правонарушениях Российской Федерации (далее КоАП РФ), внесших в него федеральным законом от 4 мая 2011г. № 97-ФЗ изменения и дополнения, в части распространения административной юрисдикции России на любое лицо, совершившее административное правонарушение за пределами Российской Федерации, а также определения порядка взаимодействия российских органов, осуществляющих производство по делам об административныхправонарушениях, с компетентными органами иностранных государств и международными организациями.

Ключевые слова:административная юрисдикция, договор о правовой помощи, принцип взаимности, административное преследование

\section{Abstract}

This article attempts to analyze the degree of effectiveness of the norms Of the code of administrative offences of the Russian Federation (hereinafter the administrative Code), introduced into it by the Federal law of may 4, 2011. № 97-FZ amendments and additions, in terms of extending the administrative jurisdiction of Russia to any person who has committed an administrative offense outside the Russian Federation, as well as determining the order of interaction of the Russian authorities carrying out proceedings in cases of administrative offenses with the competent authorities of foreign States and international organizations.

Keywords: administrative jurisdiction, agreement on legal assistance, the principle of reciprocity, the administrative prosecution 
Федеральным законом от 4 мая 2011г. N 97-Ф3 [1] в КоАП РФ [2] внесены изменения и дополнения, которые хотелось бы рассматривать как очередной шаг вперёд на пути борьбы с административными правонарушениями. Прежде всего, обращает на себя внимание правовая норма, закреплённая в части 2 статьи 1.8 КоАП РФ (в ред. Федерального закона от 04.05.2011 N 97-Ф3), распространяющая административную юрисдикцию России на любое лицо, совершившее административное правонарушение за пределами Российской Федерации в случаях, предусмотренных международным договором Российской Федерации.

Предыдущая формулировка рассматриваемой части 2 статьи 1.8 КоАП РФ (Федеральным законом от 24.07.2007 N 210-Ф3 [3] статьёй 1.8 была дополнена глава 1 КоАП РФ), предусматривала возможность привлечения к административной ответственности за совершение административных правонарушений за пределами Российской Федерации в случаях, предусмотренных международным договором Российской Федерации только граждан Российской Федерации и постоянно проживающих в Российской Федерации лиц без гражданства.Однако эту предусмотренную законодательством возможность, как минимум, нельзя было реализовать до вступления в силу Федерального закона от 05.04.2011 N 59-Ф3 "О ратификации Договора об особенностях уголовной и административной ответственности за нарушения таможенного законодательства таможенного союза и государств - членов таможенного союза" [4] и Федерального закона от 07.02.2011 N 13-Ф3 "О ратификации Соглашения о правовой помощи и взаимодействии таможенных органов государств членов таможенного союза по уголовным делам и делам об административных правонарушениях" [5].

Россией заключено 60 международных договоров, конвенций и соглашений о правовой помощи [6], но практически все они распространяют своё действие на правоотношения по гражданским, семейным, торговым и уголовным делам.

В настоящее время действуют международный договор, заключённый Россией, Республикой Беларусь, Республикой Казахстан, Республикой Армения и Кыргызской Республикой (в ред. Договора от 10.10.2014, Протокола от 08.05.2015) “Об особенностях уголовной и административной ответственности за нарушения таможенного законодательства таможенного союза и государств - членов таможенного союза о правовой помощи и взаимодействии таможенных органов государств - членов таможенного союза по уголовным делам и делам об административныхправонарушениях" и Соглашение, к которому пришли вышепоименованные государства, “О правовой помощи и взаимодействии таможенных органов государств - членов таможенного союза по уголовным делам и делам об административных правонарушениях" (заключено в г. Астане 05.07.2010) (ред. от 08.05.2015). Но сфера применения указанных договора и соглашения ограничена только оказанием правовой помощи по уголовным делам, находящимся в производстве таможенных органов, и по делам об административных правонарушениях в области таможенного дела.

Тем не менее, несмотря на то, что пока практически отсутствуют международные договоры Российской Федерации о правовой помощи по делам об административных правонарушениях, изменения и дополнения, внесённые в Кодекс (особенно его дополнение главой 29.1) нельзя недооценивать. Но в то же время к этим изменениям и дополнениям представляется необходимым относиться критично, т.к. при систематическом анализе норм главы 29.1 КоАП РФ возникает подозрение в их жизнеспособности, действенности.

Итак, по порядку, сначала о позитивном аспекте изменений и дополнений в КоАП РФ, а затем о сомнениях в возможности их реализации.

Нормы главы 29.1 КоАП РФ, определяющие порядок взаимодействия российских органов, осуществляющих производство по делам об административных 
правонарушениях, с компетентными органами иностранных государств и международными организациями для данного Кодекса являются новеллами. Хотя, в общем и целом не являются чем-то новым, т.к. практически дословно воспроизводят положения главы 53 Уголовно-процессуального кодекса Российской Федерации [7] (далее УПК РФ) с той лишь разницей, что в УПК РФ речь идёт об уголовном преследовании за совершение преступления, а в КоАП РФ об административном преследовании за совершение административного правонарушения.

Нужно отметить, что в последнее время в связи с ужесточением административной ответственности наметилась устойчивая тенденция по заимствованию законодательством об административных правонарушениях уголовно-правовых положений. Однако, представляется, что переложение уголовно-правовых норм на административно-правовую почву должно быть последовательным и не порождать правовых пробелов. Такая рецепция правовых идей одной отрасли права другой отраслью, по справедливому замечанию Разуваева Н.В., должна иметь в своей основе диалогическую установку, которая может считаться весьма продуктивной для научного познания, поскольку создаёт предпосылки для взаимодействия различных областей знания, их междисциплинарного сотрудничества и синтеза [8].

Дополнение КоАП РФ главой 29.1, в семи статьях которой определяется порядок оказания правовой помощи по делам об административных правонарушениях, явление, безусловно, положительное. До принятия рассматриваемого федерального закона от 4 мая 2011 г. N 97-Ф3 регламентация вопросов международного сотрудничества в сфере производства по делам об административных правонарушениях сводилась к части 3 статьи 26.9 КоАП РФ отсылочного характера, в соответствии с которой взаимодействие органов, осуществляющих производство по делам об административных правонарушениях, с компетентными органами иностранных государств и международными организациями осуществляется в порядке, предусмотренном законодательством Российской Федерации. При этом под таким порядком следует понимать исключительно положения Международной конвенции о взаимном административном содействии в предотвращении, расследовании и пресечении таможенных правонарушений (Найроби, 9 июня 1977 г.) [9] и принятыми на её основе приказами Федеральной таможенной службы от 27 июля 2006 г. N 703 "Об утверждении Инструкции о порядке подготовки международных запросов по делам об административных правонарушениях и в связис проведением оперативных проверок" [10], от 25.07.2014 N 1437 "Об утверждении Инструкции о порядке подготовки и направления запросов о правовой помощи по делам об административных правонарушениях, международных запросов в связи с проведением проверок по делам и материалам, находящимся в производстве оперативных подразделений таможенных органов Российской Федерации, исполнения запросов таможенных служб, компетентных органов иностранных государств и международных правоохранительных организаций" [11].

Названные Конвенция (предусматривает) и Приказы ФТС, которые предусматривали (утратили силу в связи с изданием приказа ФТС России от 13.01.2016 № 19 [12]) практически лишь обмен правоохранительной информацией между российскими таможенными органами и таможенными службами иностранных государств. При чём в соответствии с положениями указанных приказов ФТС основанием для исполнения международных запросов таможенных служб иностранных государств и международных правоохранительных организаций являлось наличие соответствующей международной договорно-правовой базы, предусматривающей обмен правоохранительной информацией.

Сейчас главой 29.1 КоАП РФ предусмотрен не только обмен правовой информацией между российскими и иностранными правоохранительными органами, но и осуществление административного преследования как в отношении гражданина 
Российской Федерации, совершившего административное правонарушение на территории иностранного государства и возвратившегося в Российскую Федерацию, или российского юридического лица, совершившего административное правонарушение за пределами территории Российской Федерации, так и в отношении иностранного юридического лица илииностранного гражданина, совершившего административное правонарушение на территории Российской Федерации и впоследствии оказавшимся за её пределами.При этом нормами рассматриваемой главы устанавливается, во-первых, что запрос о правовой помощи направляется соответствующему должностному лицу или в орган иностранного государства в соответствии с международным договором Российской Федерации или на началах взаимности, которая предполагается, пока не доказано иное и, во-вторых, суд, должностные лица федеральных органов исполнительной власти исполняют переданные им в установленном порядке запросы о правовой помощи по делам обадминистративных правонарушениях, поступившие от соответствующих компетентных органов и должностных лиц иностранных государств, в соответствии с международными договорами Российской Федерации или на началах взаимности, которая предполагается, пока не доказано иное.

Данные нормы свидетельствуют о том, что осуществление правовой помощи по делам об административных правонарушениях может производиться не только на основе заключённых международных договоров, но и в упрощённом порядке посредством подтверждения принципа взаимности письменным обязательством компетентного органа оказать от имени Российской Федерации правовую помощь иностранному государству по делам об административных правонарушениях. Но тут нужно заметить, что если в статье 453 УПК РФ (Направление запроса о правовой помощи) эти органы, полномочные подтверждать принцип взаимности письменным обязательством, исчерпывающим образом определены, то статья 29.1.1 КоАП РФ (Направление запроса о правовой помощи) хранит молчание об этих органах, называя лишь органы, через которые направляется запрос о правовой помощи.

Кроме того, является очевидным, что статусы международного договора Российской Федерации и письменного обязательства Верховного Суда Российской Федерации, Министерства юстиции Российской Федерации, Министерства внутренних дел Российской Федерации, Федеральной службы безопасности Российской Федерации или Генеральной прокуратуры Российской Федерации оказать от имени Российской Федерации правовую помощь иностранному государству по делам об административных правонарушениях, подтверждающих принцип взаимности, далеко нетождественны. Первый (международный договор Российской Федерации) является актом большей юридической силы, чем письменное обязательство названных государственных органов. В связи, с чем можно сделать вывод о наличии пробела в норме части 2 статьи 1.8 КоАП РФ, устанавливающей, что лицо, совершившее административное правонарушение за пределами Российской Федерации, подлежит административной ответственности в соответствии с КоАП РФ в случаях, предусмотренных международным договором Российской Федерации. Иными словами, если отсутствует международный договор, то нет и административной ответственности.

Законодателю, изменяя редакцию части 2 статьи 1.8 КоАП РФ, и дополняя Кодекс об административных правонарушениях Российской Федерации главой 29.1 посредством заимствования положений УПК РФ, не лишним было бы обратить внимание и на нормы статьи 12 Уголовного кодекса Российской Федерации [13], определяющих порядок действия уголовного закона в пространстве. Положения этой статьи сформулированы следующим образом:

1. Граждане Российской Федерации и постоянно проживающие в Российской Федерации лица без гражданства, совершившие вне пределов Российской Федерации преступление против интересов, охраняемых настоящим Кодексом, подлежат уголовной 
ответственности в соответствии с настоящим Кодексом, если в отношении этих лиц по данному преступлению не имеется решения суда иностранного государства.

2. Военнослужащие воинских частей Российской Федерации, дислоцирующихся за пределами Российской Федерации, за преступления, совершенные на территории иностранного государства, несут уголовную ответственность по настоящему Кодексу, если иное не предусмотрено международным договором Российской Федерации.

3. Иностранные граждане и лица без гражданства, не проживающие постоянно в Российской Федерации, совершившие преступление вне пределов Российской Федерации, подлежат уголовной ответственности по настоящему Кодексу в случаях, если преступление направлено против интересов Российской Федерации либо гражданина Российской Федерации или постоянно проживающего в Российской Федерации лица без гражданства, а также в случаях, предусмотренных международным договором Российской Федерации или иным документом международного характера, содержащим обязательства, признаваемые Российской Федерацией, в сфере отношений, регулируемых настоящим Кодексом, если иностранные граждане и лица без гражданства, не проживающие постоянно в Российской Федерации, не были осуждены в иностранном государстве и привлекаются к уголовной ответственности на территории Российской Федерации.

Учитывая всё вышесказанное, представляется, что в целях формирования эффективного законодательства об административных правонарушениях и правильного его применения необходимо внести в Кодекс об административных правонарушениях Российской Федерации следующие изменения:

1) часть 2 статьи 1.8 изложить в следующей редакции:

"2. Лицо, совершившее административное правонарушение за пределами Российской Федерации, подлежит административной ответственности в соответствии с настоящим Кодексом, а также в случаях, предусмотренных международным договором Российской Федерации или иным документом международного характера, содержащим обязательства, признаваемые Российской Федерацией, в сфере отношений, регулируемых настоящим Кодексом, если указанное лицо не было привлечено за совершение соответствующих противоправных деяний к уголовной или административной ответственности в иностранном государстве , а также в случаях, предусмотренных частью 3 настоящей статьи.”;

2) статью 29.1.1 дополнить частью 1.1 определяющей перечень государственных органов, полномочных подтверждать принцип взаимности письменным обязательством оказать от имени Российской Федерации правовую помощь иностранному государству по делам об административных правонарушениях.

При невнесении в КоАП РФ предлагаемых изменений и дополнений, нормы части 2 статьи 1.8 и главы 29.1 КоАП РФ начнут “работать” только с момента вступления в силу международных договоров о правовой помощи по делам об административных правонарушениях, которые ещё нужно заключить.

1. О внесении изменений в Уголовный кодекс Российской Федерации и Кодекс Российской Федерации об административных правонарушениях в связи с совершенствованием государственного управления в области противодействия коррупции. Федеральный закон от 04.05.2011 N 97-Ф3 (ред. от 04.06.2014) // Собрание законодательства РФ, 09.05.2011, N 19, ст. 2714.

2. Кодекс Российской Федерации об административных правонарушениях от 30.12.2001 N 195-Ф3 (ред. от 05.02.2018) // Собрание законодательства РФ", 07.01.2002, N 1 (ч. 1), ст. 1.

3. О внесении изменений в Кодекс Российской Федерации об административных правонарушениях. Федеральный закон от 24.07.2007 N 210-Ф3 (ред. от 31.12.2014) // Собрание законодательства РФ", 30.07.2007, N 31, ст. 4007.

4. О ратификации Договора об особенностях уголовной и административной ответственности за нарушения таможенного законодательства таможенного союза и государств - членов таможенного 
союза. Федеральный закон от 05.04.2011 N 59-Ф3 // Собрание законодательства РФ, 11.04.2011, N 15, ст. 2032.

5. О ратификации Соглашения о правовой помощи и взаимодействии таможенных органов государств членов таможенного союза по уголовным делам и делам об административных правонарушениях. Федеральный закон от 07.02.2011 N 13-Ф3 // Собрание законодательства РФ", 14.02.2011, N 7, ст. 910.

6. Международные договоры Российской Федерации о правовой помощи [Электронный ресурс] / СПС «КонсультантПлюс». URL: http://www.consultant.ru/document/cons_doc_LAW_126898/ (дата обращения: 25.03.2018).

7. У Угловно-процессуальный кодекс Российской Федерации от 18.12.2001 N 174-Ф3 (ред. от 31.12.2017) // Собрание законодательства РФ, 24.12.2001, N 52 (ч. I), ст. 4921.

8. Разуваев Н. В. Государство как философско-правовая категория // Управленческое консультирование. 2011. Дело № 2. П. 70.

9. Международная конвенция о взаимном административном содействии в предотвращении, расследовании и пресечении таможенных правонарушений (Вместе с Приложением X "Помощь в борьбе с контрабандой наркотических средств и психотропных веществ") (Заключена в г. Найроби 09.06.1977) // Таможенные ведомости. 1996. N 11. С. 103 - 117.

10. Об утверждении Инструкции о порядке подготовки международных запросов по делам об административных правонарушениях и в связи с проведением оперативных проверок. Приказ Федеральной таможенной службы от 27 июля 2006 г. N 703 // Официальный сайт Федеральной таможенной службы России [Электронный ресурс] https:/customs.consultant.ru/documents/3821 (дата обращения: 25.03.2018).

11. Об утверждении Инструкции о порядке подготовки и направления запросов о правовой помощи по делам об административных правонарушениях, международных запросов в связи с проведением проверок по делам и материалам, находящимся в производстве оперативных подразделений таможенных органов Российской Федерации, исполнения запросов таможенных служб, компетентных органов иностранных государств и международных правоохранительных организаций. Приказ Федеральной таможенной службы от 25.07.2014 N 1437 // Таможенные ведомости, N 10, 2014 (Извлечение).

12. Приказ ФТС России от 13.01.2016 № 19 [Электронный ресурс] / CПС «КонсультантПлюс». URL: http://www.consultant.ru/cons/cgi/online.cgi?req=doc;base=EXP;n=594356\#08741202036635889 (дата обращения: 25.03.2018).

13. Уголовный кодекс Российской Федерации от 13.06.1996 N 63-Ф3 (ред. от 31.12.2017) // Собрание законодательства РФ, 17.06.1996, N 25, ст. 2954.

\section{Попов А.В. \\ К вопросу о новой редакции диспозиции нормы об административной ответственности за осуществление предпринимательской деятельности без государственной регистрации}

Межрайонная инспекиия Федеральной налоговой службы № 12 по Омской области (Россия, Омск)

doi:10.18411/lj-31-03-2018-67

idsp: 000001:lj-31-03-2018-67

\section{Аннотация}

В статье анализируется новая редакция диспозиции нормы об административной ответственности за осуществление предпринимательской деятельности без государственной регистрации, регламентированной частью 1 статьи 14.1 Кодекса Российской Федерации об административных правонарушениях (далее - КоАП РФ), предусмотренная Федеральным законом от 29 июля 2017 г. № 265-Ф3 «О внесении изменений в Кодекс Российской Федерации об административных правонарушениях в части усиления ответственности за незаконную продажу алкогольной продукции». Автор доказывает, что рассматриваемая законодательная новелла не может быть применена в полной мере, и приходит к выводу, что в новой редакции части 1 статьи 14.1 КоАП РФ законодателю при описании случаев, когда последняя не подлежит применению, следовало указать не на часть 1 , а на часть 2 статьи 14.17.1 КоАП РФ.

Ключевые слова: административная ответственность, незаконное предпринимательство, предпринимательская деятельность без регистрации, незаконный 